Psychological and pedagogical problems of modern specialist formation

UDC [004.855+608.7::008]-043.83-057.4:658.286

DOI 10.26697/9789669726094.2017.93

\author{
(C) Perezva E., Mironenko S., 2017 \\ Elena Perezva, \\ Sergey Mironenko \\ Odessa Automobile and Road College \\ Odessa National Polytechnic University

\section{THE FORMATION OF COMPUTER LITERACY AND INFORMATION CULTURE AMONG FUTURE SPECIALISTS OF THE TRANSPORT INDUSTRY}

Present the problems of technological education; the issues of increasing the effectiveness of the educational process and pedagogical skill; specificity of teaching computer disciplines for students studying in the specialty "Transport Technologies»; particular qualities of studying computer science and computer technologies in specialties connected with transport and its processes.

Keywords: technological education, pedagogical skills, transport technologies, educational process.

\title{
Introduction
}

The problems of the formation of computer literacy among the younger generation and the application of information technologies in the educational process were concerned by a lot of researchers as I. T. Zaretskaya, L. P. Babenko, B. Kolodyazhny, N. V. Morse, V. Y. Bykov and many others. Based on the practical advice of these authors, their theoretical materials, teachers and students very often use them in their educational activities, but the problems of development and effective use of information and communication technologies in education are still very relevant in modern Ukraine. Create conditions which would most effectively operated such information space and an appropriate educational environment, which would be for the students as comfortable and interesting, would encourage them to self-development, have stepped up their cognitive activity, develop their critical thinking and ability to analyze. All of that is the purpos that should be tried to reach not only by teachers in the field, but the government generally.

So information and communication technologies (ICT) are rapidly developing, accelerating all the processes of scientific, technical and social development of the country, influencing the nature of the development of pedagogical systems and the education system as a whole. However, to ensure the integration of Ukrainian education system into the European and 
world educational space, we should take steps to modernize the target and technological aspects of education, based on widespread use of ICT. Informatization of education system is a through, comprehensive directions of innovative development of the education system, resources are still not used properly [3].

In our country there are many problems and difficulties that have a negative impact on the development of education informatization process, including the following:

- in the state are not defined strategic goals and development objectives, no long-term and medium-term forecasting and planning of socio-economic development, as envisaged in the developed world and the European Union;

- critical state of national scientific and technical sphere is largely due to the lack of an effective system of public administration science, would be responsible advocated compliance with the law and the current needs of the development of national science and provide its interaction with the production, carried out the necessary coordination of research and development [1];

- imperfection of the legislation on the use of ICT in education;

- a large number of documents (in the form of reports, plans, etc.), must be systematically filled by teachers and through the fact that there is no time for self-education;

- the constant change of curricula also reduces the effectiveness of the work of teachers is one of the reasons for the acceleration of their «teacher burnout»;

- insufficient financing of educational institutions and, accordingly, low motivation of teachers and many other problems.

In modern conditions, developed countries, in which science plays the role of the main economic-reproduction factor, ensure their development through science, the improvement of existing technologies, technology and the use of fundamentally new scientific achievements.

One of the most important strategic goals that the Ukrainian society should set for itself in the modern world is the search for opportunities and the introduction of effective measures aimed at enhancing the development of scientific and technical potential for accelerating the technological development of the state's economy, increasing its competitiveness and innovativeness [1].

Accordingly, information technology training in Ukraine still require some improvement to reach the international advanced level, and this is reflected in the quality of education, the level of training of future specialists and the teachers. 


\section{Psychological and pedagogical problems of modern specialist formation}

Increasing the level of computer literacy of the future specialist is an urgent issue and requires both high professional skills of the teacher himself and the availability of proper software and hardware that do not always meet modern education requirements.

\section{Materials and methods}

The Odessa Automobile and Road College of the Odessa National Polytechnic University has been working the division of transport systems for 15 years now. Taking into account the geopolitical position of Ukraine in general and the South region of Ukraine, in particular, is very predictable need for staff in areas of «Transport technologies». Today, college graduates have a demand not only in the south of Ukraine, but also in the country generally.

To ensure that the future specialist was competitive and highly qualified, on the basis of the college several theoretical and theoretical conferences of international level were held with the participation of representatives of Ghent University, employees of Odessa transport organizations and other specialists of this branch. During such events, students were given the opportunity to analyze modern transport problems, to get acquainted with the modern integrated package of multimodal transportation planning for OmniTRANS. This software is successfully used in transport planning in transportation systems, thanks to its powerful data processing center programming language and interface provides convenient. OmniTRANS transport planners a powerful set of tools used to solve a wide spectrum in the transport modeling problems. One of the main issues facing the planner is the control and management of potentially large and complex data sets that need to be collected and then used in models where a large number of options can be obtained. OmniTRANS established to carry out this difficult task, ensure effective and consistent storage of data in a relational database, and there are no restrictions on the number of zones, nodes or links that make up the transport network. In the near future this software will be introduced in the educational activities of our educational institution.

The future specialist of the transport industry should work day by day with information, presented in the form of tables of data, both textual and numeric, and analyze large amounts of data. Using the Microsoft Excel table processor, a student can perform automated calculations much faster and without errors. The use of tools such as «Finding Solutions» and «Parameter Selection» helps students solve optimization planning problems, transport tasks and other linear programming tasks. Everything has particular importance, since future professional activity will be connected with solving problems of this type. 
Using the experience of the colleges from Gent University, such as Frank Whitlock and Dominic Gillis, as well as the teachers of colleges, a methodical manual for diploma and course design for the specialties «Organization of transportation and management on motor transport», «Organization and regulation of road traffic» in the field «Transport and transport infrastructure» was developed. The aim is to familiarize students with the computer model and the design of traffic on the streets of Odessa.

The high level of methodical work of the teachers of the college, the availability of technical facilities and modern software is the basis that encourages students to work harder while performing tasks on computers. Free access to the Internet in the classroom, making tasks more effective and interesting. The use of «BlendedLearning» and Internet resources allows students to improve cognitive activity and to carry out a search operation, and allows teachers to combine traditional methods and current technology. The use of information and communication technologies in the classroom improves students' attitude to knowledge, as well as the quality of communication between students and teachers.

\section{Results}

The success of educational process will be provided only by the quality of the technologies. They are considered to be the guarantor of obtaining good pedagogical results. Although the same technology can be used by teachers with different levels of professionalism, however, there will be no significant differences in their work. The development of education in the future from these positions is not associated with an increase in professionalism, and with the introduction of high-quality technology.

Paying tribute to the idea of technological education, we cannot disagree with the opinion that it eliminates the problem of pedagogical skill. Certainly, XXI century will make adjustments to the development of pedagogical paradigms; the public functions of the teacher will change. However, it is difficult to imagine a truly humanistic society without a teacher - spiritual guide, mentor, helper, and then - a teacher who knows the art of influence, to awaken thought, to encourage, to infect [2].

In the process of teaching, the teacher must have a high level of pedagogical skill. Pedagogical skills - a set of personality traits, providing a high level of self-organization of professional activities on the basis of the reflexive.

All the components of pedagogical skill are interrelated, they inherent self-development, and not only growth under the influence of external factors. 


\section{Psychological and pedagogical problems of modern specialist formation}

So, to make teacher acted creatively, independently analyzed the results of its operations and adjusting means of the orientation of the target, it has to have a certain inner base, certain properties, characteristics, the development of which will provide professional self-development of the teacher, and through it - and student development.

The foundation of pedagogical skill is professional competence. The teacher's knowledge is addressed, on the one hand, to the discipline he teaches, and on the other hand to students whose psychology should be well-known. In preparation for the lesson, the teacher think over its contents, methodology takes into account the perception of students of a certain age group, their own capabilities. The content of professional competence is the knowledge of the subject, the methods of teaching it, pedagogy and psychology.

The criteria of the teacher's skill are expediency (in terms of direction), productivity (by results), dialogicality (by the nature of relations with students), optimality in the choice of means, creativity (in terms of content) [2].

\section{Discussion and conclusions}

The formation of information society in Ukraine determines how to direct its influence on the modernization of the education system, and indirect, associated with the emergence of a new lifestyle, a change in its quality. The rapid development of ICT, the dissemination of new methodological training systems create conditions for unlimited access of all subjects of education to electronic educational resources. This process is gaining in scale and intensity, and its results convince that there is no alternative for ICT in the modern world [3]. However, in Ukraine there are still unresolved problems that hinder maximum efficiency of the introduction of ICT in the education system, so the question remains open.

The need for effective use of modern computer-oriented training systems to ensure the harmonious development, training and education of students, requiring the teacher high professional competence and pedagogical skills. To effectively form a future specialist, the teacher needs not only as a source of knowledge, but also as a navigator on the life path of personality formation, providing the cardinal needs of the student in selfactualization.

To achieve this goal it is necessary to create such a comfortable environment in which students and teachers will be able to develop and implement as much as possible their abilities, knowledge and skills, but it is necessary to consolidate the efforts of not only the teachers and management of individual schools, and first and foremost the government. 


\section{References}

1. Postanova Verkhovnoi Rady Ukrainy «Pro Rekomendatsii parlamentskykh slukhan na temu: «Pro stan ta zakonodavche zabezpechennia rozvytku nauky ta naukovo-tekhnichnoi sfery derzhavy» [Resolution of the Verkhovna Rada of Ukraine «On the Recommendations of Parliamentary Hearings on the topic: «On the State and Legislative Support for the Development of Science and the Scientific and Technical Sphere of the State»]. (n.d.), zakon2.rada.gov.ua. Retrieved from http://zakon2.rada.gov.ua/laws/show/182-19 (in Ukrainian)

2. Ziaziun, I. A., Kramushchenko, L. V., \& Kryvonos, I. F. (2004). Pedahohichna maisternist [Pedagogical Excellence] (2nd ed.). Kyiv: Vyshcha shkola. (in Ukrainian)

3. Bykov, V. Y. (2011). Tekhnolohii khmarnykh obchyslen providni informatsiini tekhnolohii podalshoho rozvytku informatyzatsii systemy osvity Ukrainy [Cloud computing technologies - leading information technologies for the further development of the informatization of the Ukrainian education system]. Kompiuter u shkoli ta simi-Computer in school and family, 6, 3-11. (in Ukrainian)

Олена Перезва,

Сергій Мироненко.

Формування комп'ютерної грамотності та інформаційної культури в майбутнього фахівця транспортної галузі.

Відображено проблеми технологізаиії освіти, питання підвищення ефективності навчального процесу, педагогічну майстерність $i$ викладання комп'ютерних дисчиплін для студентів, які навчаються за спеціалізацією «Транспортні технології»; особливості вивчення інформатики та комп'ютерних технологій на спеціальностях, які пов'язані з транспортом та процесами, які пов'язані з ним.

Ключові слова: технологізація освіти, педагогічна майстерність, транспортні технологї, навчальний процес.

Elena Perezva, Sergey Mironenko. Ksztaltowanie komputerowego piśmiennictwa i kultury informacyjnej u przyszlego fachowca branży transportowej.

Przedstawiono tu problem innowacji edukacji, rozpatrzono zagadnienia dotyczące podwyższenia efektywności procesu edukacyjnego i umiejętności pedagogicznych; ukazano specyfike wyktadania przedmiotów informatycznych dla studentów, którzy studiuja na kierunku «Technologie transportowe»; właściwości studiowania informatyki $i$ komputerowych technologii na specjalnościach, które sq zwiazane $z$ transportem $i$ skorelowanymi z nim procesami.

Stowa kluczowe: innowacja edukacji, pedagogiczne umiejętności, technologie transportowe, edukacyjny proces. 
Psychological and pedagogical problems of modern specialist formation

Information about the authors:

Perezva Elena - Lecturer, Odessa Automobile and Road College Odessa National Polytechnic University.

Mironenko Sergey - Doctor of Philosophy in Techniques, Docent, Director, Odessa Automobile and Road College Odessa National Polytechnic University. 